\title{
NEW INSIGHTS INTO THE PHYLOGEOGRAPHY OF THE OIL PALM PEST, Metisa plana TOWARDS ITS MANAGEMENT CONTROL
}

\author{
AQILAH SAKINAH BADRULISHAM ${ }^{1}$; DAISUKE KAGEYAMA ${ }^{2}$; MADIHAH HALIM'; \\ AMEYRA AMAN-ZUKI'; MOHAMED MAZMIRA MASRI ${ }^{3}$; SITI NURULHIDAYAH AHMAD'; \\ BADRUL MUNIR MD-ZAIN ${ }^{4}$ and SALMAH YAAKOP ${ }^{1 *}$
}

\begin{abstract}
Metisa plana Walker, has contributed as an important pest in the palm oil industry. Even though various studies have been conducted on M. plana there is still insufficient information on the relationships among the populations to illustrate the distribution of this species. We aim to investigate the phylogeography of the M. plana populations by combining data of cytochrome c oxidase subunit I (COI), cytochrome b (Cytb), and $28 \mathrm{~S}$ markers. The M. plana specimens have been sampled from 10 heavily infested oil palm plantations in Peninsular Malaysia. A total of 145 sequences of three markers were combined and implemented for the phylogenetic analyses, Neighbour-Joining (NJ) and Bayesian Inference (BI). Both phylogenetic trees showed mixing of individuals of the M. plana inter-populations, despite a very distinct geographical isolation. Based on findings from the haplotype analyses; haplotype diversity ( $H d=0.96089)$, haplotype number (27), haplotype network, and haplotype tree; all supported the genetic exchange, indicating the possibility of gene flow. The genetic exchange occurs probably due to the flying ability of the male moth or caused by the human activities between the various plantations that accidently resulted in the transportation and movement of the pest larvae. Interestingly, the haplotype network has also been visualised in estimating the origin of the infestation, which most probably originated from three different plantations, resulting in the rapid outbreaks of the M. plana infestation. These fundamental data are very crucial and informative in the effort to strategise the management control of the M. plana.
\end{abstract}

\section{Keywords: bagworm, distribution, gene flow, Malaysia, mtDNA, nuclear.}

Received: 18 March 2021; Accepted: 4 October 2021; Published online: 3 December 2021.

1 Centre for Insect Systematics,

Department of Biological Science and Biotechnology,

Faculty of Science and Technology,

Universiti Kebangsaan Malaysia,

43600 Bangi, Selangor, Malaysia.

2 Institute of Agrobiological Sciences,

National Agriculture and Food Research Organization (NARO), Owashi, Tsukuba, Ibaraki, 308-0851, Japan.

3 Malaysian Palm Oil Board, 6 Persiaran Institusi, Bandar Baru Bangi, 43000 Kajang, Selangor, Malaysia.

4 Department of Biological Science and Biotechnology, Faculty of Science and Technology,

Universiti Kebangsaan Malaysia, 43600 Bangi, Selangor, Malaysia.

* Corresponding author e-mail: salmah78@ukm.edu.my

\section{INTRODUCTION}

Bagworms (Lepidoptera: Psychidae) are among some of the most notorious pests of oil palm (Elaeis guineensis Jacquin) in palm oil-producing countries. Pteroma pendula and Metisa plana Walker are two species of bagworms that have been reported to attack oil palm plantations in Peninsular Malaysia. Outbreaks of $M$. plana have been reported in Malaysia in the 1960s due to excessive application of insecticides (Wood and Kamaruddin, 2019). The attacks had also occurred in other countries such as Indonesia (Sudarsono et al., 2011) and India (Potineni and Saravanan, 2013) which had led to a reduction of yields. According to Rahmat et al. (2021), outbreaks 
of M. plana could cause up to $40 \%$ of yield loss if it remained uncontrolled over two consecutive years, due to serious defoliation of palm leaves by the larvae of M. plana (Ahmad et al., 2017; Ho et al., 2011). This issue is still becoming a concern today although various control methods are available.

Chemical control has been used widely to manage bagworms outbreak in most plantations (Ahmad et al., 2017). It is the fastest and most effective way to suppress outbreaks of M. plana. However, it leads to other problems such as resistance of pests towards the treatments, abundance of harmful chemical residues in the environment and interference of the natural enemy populations (Kamarudin et al., 2017). Currently, biological control using natural enemies has become a preferable method to suppress M. plana infestations. Previous studies have explored the use of pheromone trapping and biopesticides to control M. plana, resulting in decreased crop damage (Ahmad et al., 2017; Kamarudin et al., 2017; Salim et al., 2015). In addition, several parasitoid species were recorded attacking $M$. plana and have the potential as the dominant biological agents in controlling the infestation of bagworms naturally (Halim et al., 2018; Kamarudin and Arshad, 2016; 2019; Thaer et al., 2021).

The most outstanding feature of $M$. plana is that the pupal bag is sub-cylindrical, 9-13 $\mathrm{mm}$ long with a hook-shaped attachment on the leaf (Loong and Chong, 2012). The portable bag is constructed from silk, plastered with the debris of palm leaves, stalks and flowers during the larval and pupal stages of the pest (Rhainds et al., 2002; 2008; 2009). This feature becomes a problem in managing the infestation because of the difficulty of chemical insecticides to penetrate and have direct contact with the insects inside the bag. Sexual dimorphisms occur in M. plana, where the flightless adult female is sessile and stays in the bag for its entire life, attracting the males by secreting sex pheromones while the male would emerge from the bag upon reaching the adult stage and would fly towards the female to mate (Ali et al., 2007). This behavioural feature is crucial in understanding the dispersal of the species, which leads to outbreaks.

Phylogeography is an analysis for investigating the dispersal distribution of a pest species in order to understand its niche divergence (Godefroid et al., 2016). Thus, a comprehensive study on the biology of the M. plana is required to understand the dispersal habit of the insect species, e.g. to study the maximum distance of its flying ability, what are the contributing factors that facilitate their movement, and other possible physical factors that would contribute to the movement. Such questions could be answered by implementing specific analysis using molecular data and studies with similar objectives have been conducted by Silva-Brandao et al. (2015) and Zhang et al. (2018), among others. The mitochondrial deoxyribonucleic acid (mtDNA), cytochrome $c$ oxidase subunit I (COI) and cytochrome $b(\mathrm{Cy} t b)$ have a higher mutation rate, and are more effective in genetic population studies compared to the use of nuclear genome (Jiang et al., 2016). Besides, the mtDNA is also essential when constructing the lower classification level (Patwardhan et al., 2014).

The distribution status of individuals among inter-populations of $M$. plana has never been investigated and is the crux of the hypothesis in this study. The question of whether M. plana can fly for long distances or if it is transported across inter-populations due to human activities becomes our main research objective. To date, little is known about the current relationships between the various populations of M. plana in Peninsular Malaysia in terms of molecular proof of their relationships. Despite its economic importance, information on the distribution of the dominant oil palm pest, M. plana is very limited and rarely discussed in Malaysia. By understanding the phylogeography of the M. plana populations, the distribution of the species may be interpreted, which is important in planning control strategies. Thus, in the present study, we aim to investigate the phylogeography of the M. plana populations from 10 heavily infested oil palm plantations, using mtDNA (COI and $C y t b)$, and nuclear [28S ribosomal ribonucleic acid (rRNA)] markers.

\section{MATERIALS AND METHODS}

\section{Insect Sampling}

Specimens of M. plana were collected from 10 highly infested areas in Peninsular Malaysia, namely the northern zone (Tapah1, Tapah2, Sungkai and Slim River), the middle zone (Shah Alam and Banting) and the southern zone (Kluang, Muar, Yong Peng and Sri Medan) (Table 1, Figure 1). Metisa plana has been identified and differentiated from the other bagworm species in the field based on Loong and Chong (2012). Samplings were conducted on two occasions, from December 2015 to June 2016 and from January 2017 to December 2018, by handpicking from the upper and bottom parts of the oil palm fronds. A total of five trees were sampled randomly in $1000 \mathrm{~m}^{2}$ area to collect a total of 100 individuals per tree. However, in this study, only one individual was chosen per tree for molecular work. The sampling sites were chosen based on several outbreak reports of high infestations of bagworms by the oil palm planters (Muhammad Adhni Rusli, 2018). Larval bagworms were differentiated from the adult females by their morphological bag design and the length of the bag following Kok et al. (2011). The collected samples were stored in $70 \%$ alcohol and at $-20^{\circ} \mathrm{C}$ prior to DNA extraction. 


\begin{tabular}{lc}
\multicolumn{2}{c}{ TABLE 1. SAMPLING LOCATIONS OF Metisa plana AND ITS } \\
GLOBAL POSITIONING SYSTEM (GPS) COORDINATES \\
\hline \multicolumn{1}{c}{ Study location } & \multicolumn{1}{c}{ GPS coordinate } \\
\hline Perak: Tapah1 & $4^{\circ} 10^{\prime} 46.2^{\prime \prime} \mathrm{N} 101^{\circ} 11^{\prime} 36.5^{\prime \prime} \mathrm{E}$ \\
Perak: Tapah2 & $4^{\circ} 09^{\prime} 23.2^{\prime \prime} \mathrm{N} 101^{\circ} 16^{\prime} 22.5^{\prime \prime} \mathrm{E}$ \\
Perak: Sungkai & $3^{\circ} 50^{\prime} 54.0^{\prime \prime} \mathrm{N} 101^{\circ} 17^{\prime} 19.0^{\prime \prime} \mathrm{E}$ \\
Perak: Slim River & $3^{\circ} 48^{\prime} 23.8^{\prime \prime} \mathrm{N} 101^{\circ} 22^{\prime} 56.8^{\prime \prime} \mathrm{E}$ \\
Selangor: Shah Alam & $3^{\circ} 13^{\prime} 57.5^{\prime \prime} \mathrm{N} 101^{\circ} 22^{\prime} 36.6^{\prime \prime} \mathrm{E}$ \\
Selangor: Banting & $2^{\circ} 48^{\prime} 10.9^{\prime \prime} \mathrm{N} 101^{\circ} 27^{\prime} 26.8^{\prime \prime} \mathrm{E}$ \\
Johor: Kluang & $1^{\circ} 57^{\prime} 20.0^{\prime \prime} \mathrm{N} 103^{\circ} 22^{\prime} 15.1^{\prime \prime} \mathrm{E}$ \\
Johor: Muar & $2^{\circ} 03^{\prime} 28.1^{\prime \prime} \mathrm{N} 102^{\circ} 36^{\prime} 24.6^{\prime \prime} \mathrm{E}$ \\
Johor: Yong Peng & $2^{\circ} 08^{\prime} 37.8^{\prime \prime} \mathrm{N} 103^{\circ} 02^{\prime} 23.3^{\prime \prime} \mathrm{E}$ \\
Johor: Sri Medan & $1^{\circ} 58^{\prime} 45.0^{\prime \prime} \mathrm{N} 102^{\circ} 57^{\prime} 25.0^{\prime \prime} \mathrm{E}$
\end{tabular}

\section{DNA Extraction}

Five individual larvae from each locality were used for molecular work with a total of 50 larvae (Table 2). Each specimen was cut into half to expose the tissues and then submerged in the buffer MG and proteinase $\mathrm{K}$ for the lysis process (Halim et al., 2018). Total DNA was extracted using the NucleoSpin ${ }^{\circledR}$ DNA Insect (MachereyNagel, Germany) according to the manufacturer's protocol. The DNA samples were stored at $-20^{\circ} \mathrm{C}$.

\section{Polymerase Chain Reaction (PCR) Amplification}

A partial sequence of COI (646 bp) was amplified using a pair of primers from Folmer et al. (1994), while Cytb (417 bp) from Simmons and Weller (2001) and $28 \mathrm{~S}$ rRNA gene (486 bp) was amplified using a forward primer from Belshaw and Quick (1997), whereas reverse primer was from Campbell et al. (1994). The PCR mixture and conditions followed the method by Halim et al. $(2017 ; 2018)$, while the annealing temperatures used for M. plana were $45^{\circ} \mathrm{C}$ for $\mathrm{COI}, 50^{\circ} \mathrm{C}$ for $\mathrm{Cy} t b$ and $48.7^{\circ} \mathrm{C}$ for $28 \mathrm{~S}$ rRNA, respectively. The successful PCR products were purified using QIAquick Purification Kit (Qiagen) and sequenced by Apical Scientific Sdn. Bhd. (Selangor, Malaysia).

\section{DNA Sequence Data and Analysis}

All the sequences obtained were edited using Sequencher v4 (GeneCodes Corporation). Each sequence was subjected to Basic Local Alignment Search Tool (BLAST) in National Center for Biotechnology Information (NCBI) (https: / blast.ncbi. nlm.nih.gov/) for the reliability of the results (Benson et al., 2013) based on the percentage of similarity, evenness and probability values (E) with the data in GenBank (Krauthammer et al., 2000). The dataset was

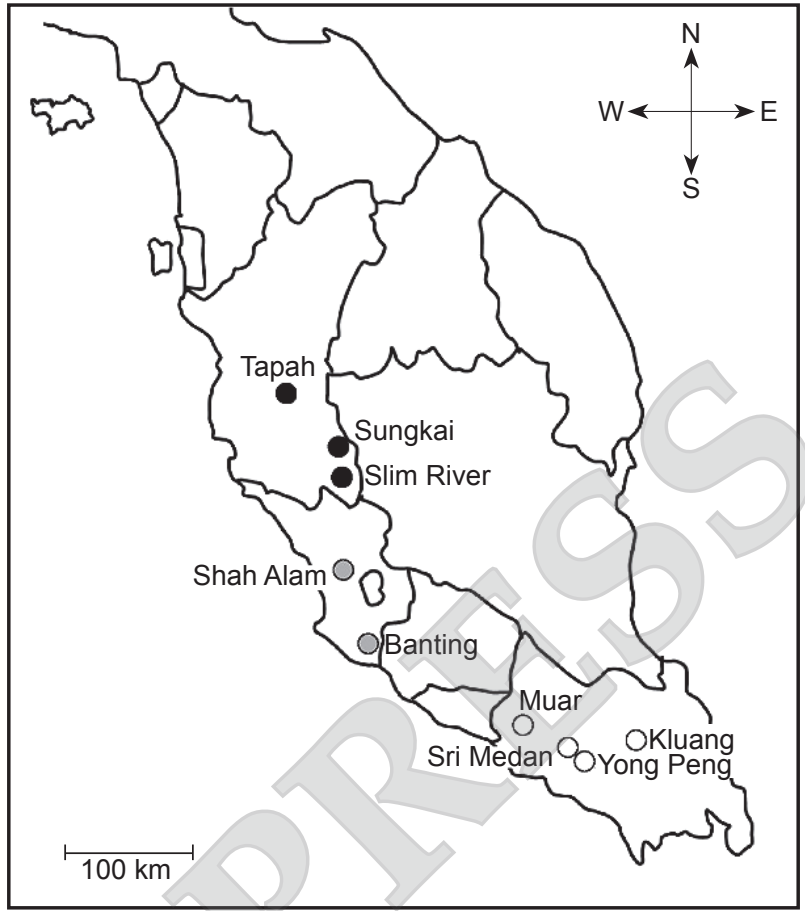

Figure 1. Sampling sites of M. plana in Peninsular Malaysia.

aligned with the outgroup, Pteroma pendula for COI and Cytb, while Celastrina argiolus (AY556547) for $28 \mathrm{~S}$ using ClustalW multiple alignments (Thompson et al., 1994) in MEGA7 software (Kumar et al., 2016).

\section{Incongruence Length Differences (ILD) Test}

A total of 145 sequences of $M$. plana had been concatenated (28S, COI and Cytb) into a single data set by using MacClade ver. 3 software. ILD test was then conducted using PAUP version $4.0 \mathrm{~b} 10$ (Swofford, 2002) to test the homogeneity of COI, Cytb and $28 \mathrm{~S}$ rRNA region in order to combine for further phylogenetics analysis.

\section{Phylogenetic Analysis}

Phylogenetic analysis was conducted on the combined data using Neighbour-Joining (NJ) and Bayesian Inference (BI) analysis. The NJ tree was generated by using distance criterion and 1000 replications following Kimura 2-Parameter substitution model, where the robustness of the tree was estimated using bootstrap analysis of 1000 replications. For Bayesian analysis, the best-fit model was selected using jModeltest 3.7 based on Akaike Information Criterion (AIC). BI tree was generated using two chains of Monte Carlo Markov Chain (MCMC) with the sample frequency of $100 \mathrm{~Hz}$. Both $\mathrm{NJ}$ and MP analysis were performed using PAUP version 4.0b10 (Swofford, 2002), while BI analysis was conducted using MrBayes version 3.1.2 (Ronquist et al., 2012). NJ tree of combined data for 20 individuals of $M$. plana were also conducted using PAUP software. 
TABLE 2. LIST OF DNA SAMPLES USED IN THIS STUDY

\begin{tabular}{|c|c|c|c|c|c|}
\hline Code & Region & Locality & COI accession no. & Cytb accession no. & $28 \mathrm{~S}$ accession no. \\
\hline OP04-3 & \multirow{20}{*}{ Northern } & \multirow{5}{*}{ Tapah1 } & KX055456 & KY448251 & MN661304 \\
\hline OP04-4 & & & KX055457 & KY448252 & MN661305 \\
\hline OP04-5 & & & KX055458 & KY448253 & MN661306 \\
\hline OP04-6 & & & KX055455 & KY448250 & MN661307 \\
\hline OP04-7 & & & KX055459 & KY448254 & n.e. \\
\hline BT1 & & \multirow{6}{*}{ Tapah2 } & MK548624 & MK804468 & MN661287 \\
\hline BT2 & & & MK548625 & MK804469 & MN661288 \\
\hline ВТ3 & & & MK548626 & MK804470 & MN661289 \\
\hline BT4 & & & MK548627 & MK804471 & MN661290 \\
\hline BT5 & & & MK548628 & MK804472 & MN661291 \\
\hline BS1 & & & MK548634 & MK548604 & n.e. \\
\hline BS2 & & \multirow{4}{*}{ Sungkai } & MK548635 & MK548605 & MN661296 \\
\hline BS3 & & & MK548636 & MK548606 & MN661297 \\
\hline BS4 & & & MK548637 & MK548607 & MN661298 \\
\hline BS5 & & & MK548638 & MK548608 & MN661323 \\
\hline BR1 & & \multirow{5}{*}{ Slim River } & MK548639 & MK548609 & MN661299 \\
\hline BR2 & & & MK548640 & MK548610 & MN661300 \\
\hline BR3 & & & MK548641 & MK548611 & MN661321 \\
\hline BR4 & & & MK548642 & MK548612 & MN661322 \\
\hline BR5 & & & MK548643 & MK548614 & MN661301 \\
\hline OP06-1 & \multirow{10}{*}{ Middle } & \multirow{10}{*}{ Shah Alam } & KX055460 & KY448260 & MN661308 \\
\hline OP06-2 & & & KX055461 & KY448261 & MN661309 \\
\hline OP06-3 & & & KX055462 & KY448262 & MN661310 \\
\hline OP06-4 & & & KX055463 & KY448263 & MN661311 \\
\hline OP06-5 & & & KX055464 & KY448264 & MN661312 \\
\hline BB1 & & & 548614 & MK548589 & MN661318 \\
\hline BB2 & & & MK548615 & MK548590 & MN661284 \\
\hline BB3 & & & MK548616 & MK548591 & MN661319 \\
\hline BB4 & & & MK548617 & MK548592 & MN661285 \\
\hline BB5 & & & n.e. & MK548583 & MN661286 \\
\hline OP16-1 & \multirow{15}{*}{ Southern } & \multirow{5}{*}{ Muar } & KX055470 & KY448270 & MN661313 \\
\hline OP16-2 & & & KX055471 & KY448271 & MN661314 \\
\hline OP16-3 & & & KX055472 & KY448272 & MN661315 \\
\hline OP16-4 & & & KX055473 & KY448273 & MN661316 \\
\hline OP16-5 & & & KX055474 & KY448274 & MN661317 \\
\hline BM1 & & \multirow{5}{*}{ Sri Medan } & MK548619 & MK548594 & MN661280 \\
\hline BM2 & & & MK548620 & MK548595 & MN661281 \\
\hline BM3 & & & MK548621 & MK548596 & MN661282 \\
\hline BM4 & & & MK548622 & MK548597 & MN661283 \\
\hline M5 & & & MK548623 & MK548598 & MN661320 \\
\hline BY1 & & \multirow{5}{*}{ Yong Peng } & MK548629 & MK548599 & MN661292 \\
\hline BY2 & & & MK548630 & MK548600 & MN661293 \\
\hline BY3 & & & MK548631 & MK548601 & MN661324 \\
\hline BY4 & & & MK548632 & MK548602 & MN661294 \\
\hline BY5 & & & MK548633 & MK548603 & MN661295 \\
\hline OP08-1 & & \multirow{5}{*}{ Kluang } & KX055465 & KY448265 & MN661325 \\
\hline OP08-2 & & & KX055466 & KY448266 & MN661302 \\
\hline OP08-3 & & & KX055467 & KY448267 & n.e. \\
\hline OP08-4 & & & KX055468 & KY448268 & MN661303 \\
\hline OP08-5 & & & KX055469 & KY448269 & n.e. \\
\hline
\end{tabular}




\section{Haplotype Analysis}

Haplotype number (n) was calculated on for the M. plana using DNA Sequence Polymorphism (DnaSP), version 5.10.01 (Librado and Rozas, 2009), as well as haplotype diversity, the Tajima's D and Fu's Fs values.

\section{Haplotype Network Analysis}

The haplotype network analysis was conducted using the software Network 5.0 (Fluxus Technology Ltd.) to visualise the relationships among haplotypes from different populations. For the haplotype tree, MEGA7 software (Kumar et al., 2016) was used to perform maximum likelihood (ML) analysis in which the robustness of the tree was assessed by 1000 bootstrap replicates.

\section{RESULTS}

\section{Sequence Analysis}

The sequences analysis of COI resulted in $637 / 646,3,6,0.46 \% ; C y t b 406 / 417,8,3,1.91 \%$, and $28 \mathrm{~S}$ rRNA $451 / 533,16,20,3.0 \%$ of conserved sites, parsimony informative, parsimony uninformative characters, and variation percentage, respectively. A value of 1510/1550 for conserved sites, 11

(a)

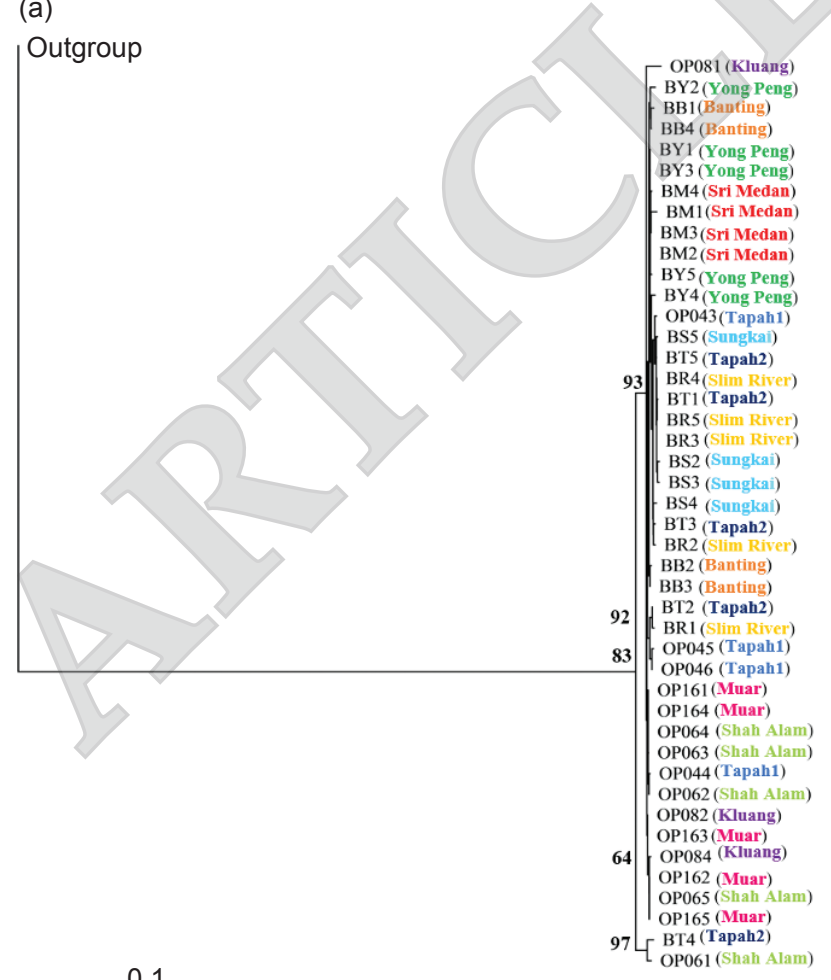

for parsimony informative characters, 27 for uninformative characters, and $0.71 \%$ variation percentage were measured from the combined datasets.

\section{ILD Test and Phylogenetic Trees}

A total of $1596 \mathrm{bp}$ of combining data of COI, Cytb and 28S, with the ILD test has shown $p=0.14$ that indicates the significance of combining the datasets. The phylogenetic trees using NJ and BI analyses also have shown the mixing of individuals in interpopulations in all analyses (Figure 2).

\section{Haplotype Analysis Data}

Based on the results of haplotype analysis (diversity and haplotype number), networks and tree have shown mixing of individuals among interpopulations (Table 3, Figures 3-4). The haplotype analysis has presented haplotype diversity, $\mathrm{Hd}=$ 0.96089. A total of 27 haplotypes had been observed from the combined data of COI, Cytb and 28S rRNA of the M. plana under 51 characters. Almost 74\%, 20 haplotypes were found to be unique and represented only in single populations. Several haplotypes (Hap1, Hap5, Hap7, Hap14, Hap20, Hap24 and Hap26) were shared between populations, whereas Hap20 showed the highest frequency. The Hap20 was presented by the largest size of network, which

(b)

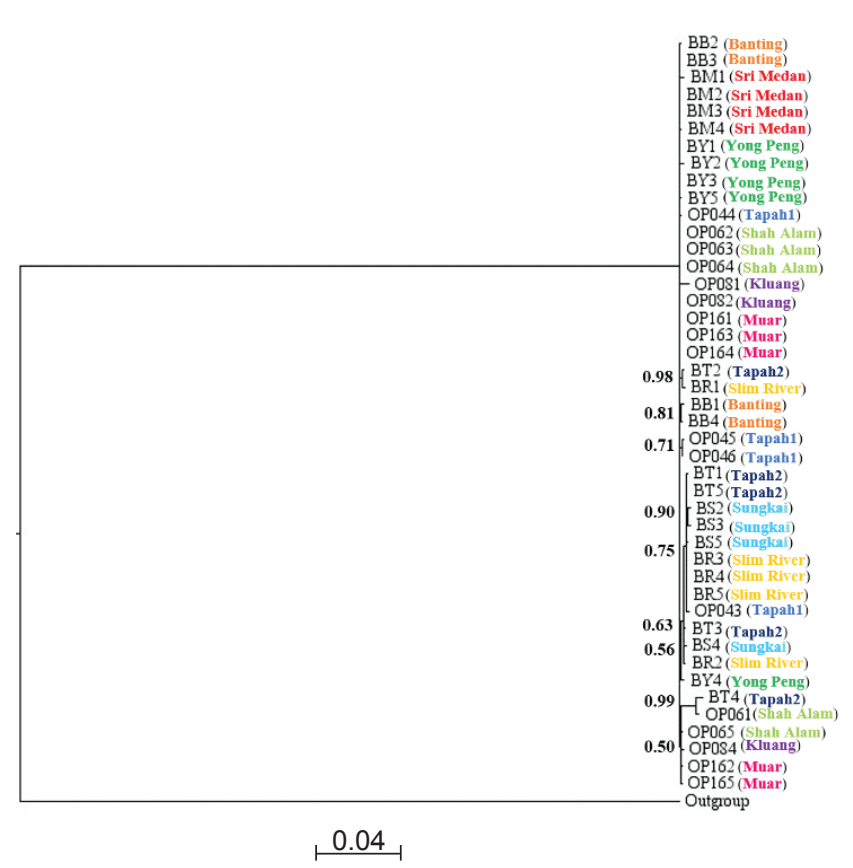

Figure 2. Phylogeography of 10 populations of M. plana based on combining three markers (COI, Cytb and 28S). (a) Neighbour-Joining (NJ) tree, and (b) Bayesian (BI) tree. 
TABLE 3. THE LIST OF SAMPLES, LOCATIONS AND THE HAPLOTYPE NUMBER

\begin{tabular}{|c|c|c|c|}
\hline & Sample & Location & Haplotype \\
\hline 1 & OP04-3 & Perak: Tapah1 & Hap19 \\
\hline 2 & OP04-4 & Perak: Tapah1 & Hap20 \\
\hline 3 & OP04-5 & Perak: Tapah1 & Hap21 \\
\hline 4 & OP04-6 & Perak: Tapah1 & Hap22 \\
\hline 5 & BT1 & Perak: Tapah2 & Hap7 \\
\hline 6 & BT2 & Perak: Tapah2 & Hap8 \\
\hline 7 & ВТ3 & Perak: Tapah2 & Hap9 \\
\hline 8 & BT4 & Perak: Tapah2 & Hap10 \\
\hline 9 & BT5 & Perak: Tapah2 & Hap7 \\
\hline 10 & BS2 & Perak: Sungkai & \\
\hline 11 & BS3 & Perak: Sungkai & Hap14 \\
\hline 12 & BS4 & Perak: Sungkai & Hap15 \\
\hline 13 & BS5 & Perak: Sungkai & Hap16 \\
\hline 14 & BR1 & Perak: Slim River & Hap17 \\
\hline 15 & BR2 & Perak: Slim River & Hap18 \\
\hline 16 & BR3 & Perak: Slim River & Hap7 \\
\hline 17 & $\mathrm{BR} 4$ & Perak: Slim River & Hap7 \\
\hline 18 & BR5 & Perak: Slim River & Hap7 \\
\hline 19 & OP06-1 & Selangor: Shah Alam & Hap23 \\
\hline 20 & OP06-2 & Selangor: Shah Alam & Hap20 \\
\hline 21 & OP06-3 & Selangor: Shah Alam & Hap20 \\
\hline 22 & OP06-4 & Selangor: Shah Alam & Hap20 \\
\hline 23 & OP06-5 & Selangor: Shah Alam & Hap24 \\
\hline 24 & BB1 & Selangor: Banting & Hap1 \\
\hline 25 & BB2 & Selangor: Banting & Hap2 \\
\hline 26 & BB3 & Selangor: Banting & Hap3 \\
\hline 27 & BB4 & Selangor: Banting & Hap1 \\
\hline 28 & OP16-1 & Johor: Muar & Hap20 \\
\hline 29 & OP16-2 & Johor: Muar & Hap24 \\
\hline 30 & OP16-3 & Johor: Muar & Hap26 \\
\hline 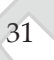 & OP16-4 & Johor: Muar & Hap20 \\
\hline 32 & OP16-5 & Johor: Muar & Hap24 \\
\hline 33 & BM1 & Johor: Sri Medan & Hap4 \\
\hline 34 & BM2 & Johor: Sri Medan & Hap5 \\
\hline 35 & BM3 & Johor: Sri Medan & Hap5 \\
\hline 36 & BM4 & Johor: Sri Medan & Hap6 \\
\hline 37 & BY1 & Johor: Yong Peng & Hap5 \\
\hline 38 & BY2 & Johor: Yong Peng & Hap11 \\
\hline 39 & BY3 & Johor: Yong Peng & Hap5 \\
\hline 40 & BY4 & Johor: Yong Peng & Hap12 \\
\hline 41 & BY5 & Johor: Yong Peng & Hap13 \\
\hline 42 & OP08-1 & Johor: Kluang & Hap25 \\
\hline 43 & OP08-2 & Johor: Kluang & Hap26 \\
\hline 44 & OP08-4 & Johor: Kluang & Hap27 \\
\hline
\end{tabular}




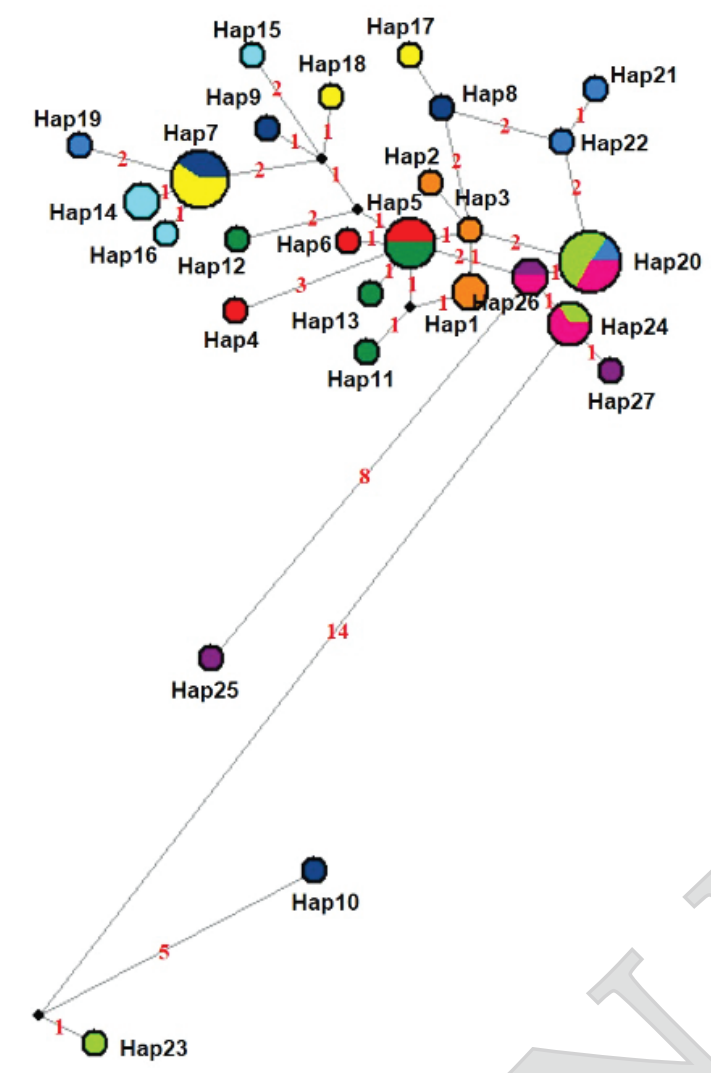

Banting

Sri Medan

Yong Peng

Tapah2

Slim River

Sungkai

Tapah1

Shah Alam

Kluang

Muar

Figure 3. Haplotype network based on the combined data (COI, Cytb and 28S) of M. plana collected from 10 populations of the pest.

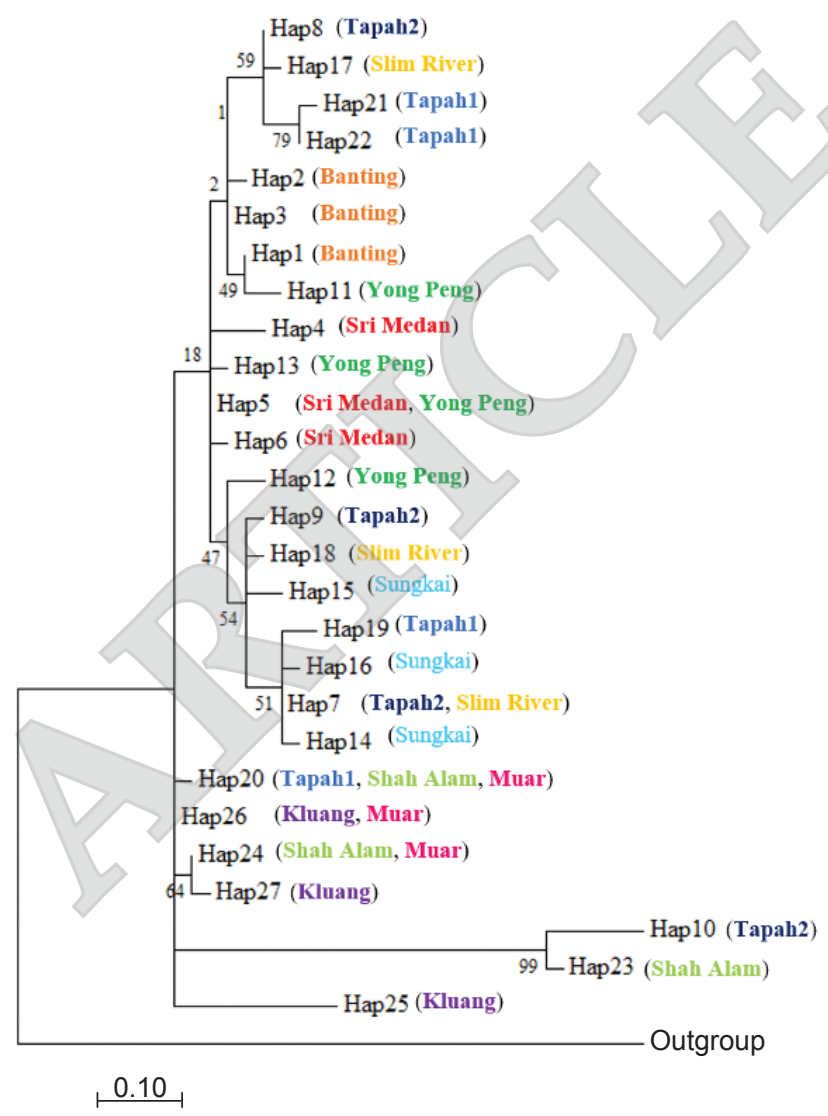

Figure 4. Haplotype tree of the combined data of COI, Cytb and $28 \mathrm{~S}$ based on ML analysis on 10 populations of M. plana. Numbers over the branches are bootstrap values based on 1000 replicates. contributed to the highest frequency (six sequences) in three populations, followed by Hap1 (2), Hap5 (4), Hap7 (5), Hap14 (2), Hap 24 (3), and Hap 26 (2). Putative relationships among the haplotypes are not resolved, in which several clades are collapsed due to unsupported bootstrap values (less than $50 \%$ ). The haplotype tree also shows the mixing of haplotypes being represented and has occurred in several localities (Figure 4).

\section{Haplotype Network}

From the network above, the dispersal of the haplotypes was found as a mixture among and between populations, with no significant correlation between haplotypes and the mutation sites, supported by Tajima's D: -1.64644 and large negative value of Fu's Fs statistic: -12.51 with no significant values, $0.10>p>0.05$ in both analyses.

\section{DISCUSSION}

This study has successfully visualise the distribution of the $M$. plana based on the phylogeographical analysis (Figure 2) as well as haplotype analyses (haplotype number, haplotype network and haplotype tree) (Figures 3-4). This approach of study was more or less similar to the study conducted by Zhang et al. (2017) and Kang et al. (2021), but 
with different objectives and samples of study. A combination of the mtDNA (COI and Cytb) and nuclear data (28S) has been used for phylogenetic analysis. The large subunit $28 \mathrm{~S}$ ribosomal RNA gene (28S rRNA) is coded on the nuclear genome and is used as an additional data to comprehend the differences between winged males and apterous females at the nuclear level. Moreover, the different coalescent times in both mitochondrial and nuclear data also are feasible to reveal the biogeographical events at different periods (Templeton, 2002). For more robust phylogeny, the combined data has been formed into one dataset to obtain more informative characters for phylogenetic analyses (Vogler and Welsh, 1997). This is likely because a combination of three markers in this study has resulted in a total of 27 informative characters, compared to 3, 8 and 16 in COI, Cytb and 28S, respectively. In order to obtain more support values for the nodes on the phylogenetic trees (Wortley et al., 2005), combination markers are suggested and this was supported by Aman-Zuki et al. (2019) who had proven that by combining mitochondrial and nuclear datasets, more robust phylogeny of the parasitic wasp, the Apanteles group was observed. In addition, Meemongkolkiat et al. (2019) and Baird et al. (2017) also presented more resolved phylogeography and phylogeny in both species of study by implementing nuclear and mtDNA.

The M. plana had been sampled from 10 infested oil palm plantations in Peninsular Malaysia. The identified M. plana DNA was isolated, sequenced and confirmed through the BLAST analysis. The same method has been performed in this study to reconfirm the species status in order to avoid including the sibling species in the analysis. It has been reported in Peninsular Malaysia that M. plana and P. pendula are primary pests and classified as siblings (Ho et al., 2011). Misidentification of those as sibling species could happen due to the resemblance in their pupal bag structure. However, Loong and Chong (2012) have extensively explained the biology of both species based on the structure of the bag when attached to the frond and also the differences in their body size. In addition, the status of the sibling laryae of the M. plana was also avoided based on the sampling method used in collecting the samples, in which only a single individual larva was collected from a single tree in this study.

The M. plana species has been found to be distributed only on the west coast of the Peninsular Malaysia, but not on the east coast (Ho et al., 2011). So far, there has been no report on the infestation of M. plana along the east coast of Peninsular Malaysia from the stakeholders and oil palm management. The east coast is physically separated from the west coast by the Titiwangsa Range $(2183 \mathrm{~km})$ that forms the backbone of Peninsular Malaysia (Tan et al., 2011), and the poor ability of M. plana to fly far across the great mountain barrier could escalate the separation of the M. plana populations. Even though physical barriers such as mountains, long rivers, etc., (Elameen et al., 2016) could become the main factors in population separation in insects and other animal species, however, this is not likely to be the case for distinct separation among populations of the M. plana in our study areas.

In this study, the 10 plantations that are highly infested by the M. plana extend $\sim 420 \mathrm{~km}$ (southKluang to north- Tapah) on the west coast of the Peninsular Malaysia. The geographical isolation is posed by several geographical barriers, namely the ranges of Gunung Ledang $(1276 \mathrm{~m})$ at the south, and Gunung Angsi $(825 \mathrm{~m})$ at the middle, and the tributaries of Sungai Perak $(400 \mathrm{~km})$ at the northern part of west Peninsular Malaysia. However, based on the phylogenetic trees (Figure 2 ), the mixing of individuals between populations is apparently neither in line nor collaborated with the geographical isolation, thus, the physical barriers can be discounted. Therefore, there could be other possible factors contributing to the dispersal distribution apart from those of physical barriers, and most likely, the species behaviour, human and abiotic factors are the more significant contributing factors (Basoalto et al., 2020; Zhang et al., 2017).

In this study, based on the phylogeographic trees among the M. plana populations it is possible to estimate their relationships to facilitate in comprehending and illustrating their flying and dispersal abilities. To date, no specific study on the flying ability of $M$. plana has been comprehensively conducted. Therefore, the capability of M. plana to fly over long or short distances has never been described properly. However, in their studies, Abdullah et al. (2012) had briefly noted that M. plana was able to fly from one palm frond to another within $100 \mathrm{~cm}$ distance, while Rhainds et al. (2002) postulated that the ballooning event of the larvae was the dispersal mechanism that could contribute to only minimal dispersal. Nevertheless, such information would not reveal much regarding the relationships between populations, nor the mechanism and dispersal distribution status. Based on the phylogeographic trees (Figure 2), we could see that several individuals of the M. plana in one location had mixed with other populations. This could either be due to their ability to fly further afield or that the larvae of the M. plana were accidentally transported and dispersed by human activities between plantations.

Based on the phylogenetic analysis of each marker (gene tree), we have found that there was a mixture between populations in all trees (28S, COI and $C y t b)$. However, the single-gene trees are not presented in this article. At first, we estimated the isolation in the population using the $\mathrm{COI}$ and $\mathrm{Cytb}$ sequences data due to the high mutation rate in the 
mitochondrial markers (Patwardhan et al., 2014). This, however, does not happen in the mtDNA in our study due to low variation detected in the sequences of COI and Cytb. Finally, the mixture between individuals from different populations was observed in both mitochondrial and nuclear data in this study.

Referring to the sequence analysis, $28 \mathrm{~S}$ rRNA showed $3.0 \%$ variation, while $0.46 \%$ and $1.91 \%$ in $C O I$ and $C y t b$, respectively. In this study, the similar sequences in $28 \mathrm{~S}$ were not sequenced in all the samples. A more detailed look into the mixing of individuals in the tree topologies would reveal that some individuals would remain static within their bags on the host fronds during their entire life, particularly those females known as flightless, wingless or apterous females. However, all the males can fly and disperse for mating and survival of the species and these males are the ones that could create the gene flow between populations (Abdullah et al., 2012). This might contribute to the differences in the sequences that were derived from different male parents' information. Furthermore, the larvae of the M. plana might also be dispersed by wind, animals or human activities across plantations due to the unique structure of the larval bags, which were hung in an upright position on their long silken threads (Kok et al., 2011; Thaer et al., 2021) which could also lead to the mixture between populations in all markers.

The bagworm $M$. plana is known as a polyphagous insect and may feed on other plant materials within the vicinity of the oil palm plantation (Kamarudin et al., 2017). This type of feeding behaviour and food range may contribute to the minimal dispersal activity of this bagworm species. During our sampling process, the gender of the larval stages (between 5-7 instars) has not been determined and predicted, but this can be accomplished by experienced field technicians or researchers. The gender of the male larvae during that stage may be identified by the blackish head colouration for the males, and pale colour for the females. Thus, our samplings have involved the collection of both male and female specimens.

The high application of chemical insecticides to control the population of M. plana would not change the genetic information of the species due to the thickness of the bag which was not affected much by the chemical residues (Loong and Chong, 2012). We also tried to reduce and minimise the mistakes in identifying the pseudogenes through the proper alignment with the parent sequences to make sure all had translated to the functional protein (Harrison et al., 2005). It indicated a sign of pseudogenes in two COI samples (OP06-1 and BT4), however we had reconfirmed that no pseudogenes appeared, and that both were referred to the M. plana after multiple checking.
The haplotype diversity based on both mitochondrial and nuclear data for all samples showed high value of 0.96089 , indicating a high number of sequence variation in the population (Liu et al., 2006), and also high genetic similarity between populations (Tan et al., 2016). In our work, 27 haplotypes were observed, while 20 haplotypes were single and seven haplotypes were shared. Even though the 20 haplotypes are found in single frequency, it has proven that the genetic information is not shared between populations (Mohd-Yusof et al., 2019), but is able to support the mixing between populations only for seven haplotypes. Hap 20 was the most shared between the M. plana populations under six frequencies. The distribution of haplotypes was also correlated with geographical factors which supported the mixing between individuals from different populations as shown in the phylogenetic tree (Figure 2). Even though the M. plana has minimal dispersal ability, human activities might have contributed to the sharing of haplotypes between the northern, middle and southern populations. The haplotype network and tree (Figures 3-4) are the two indicators to determine the variations in the nucleotide sequences for haplotype data (Paradis, 2018). In this study the origins of the infestation had occurred simultaneously from three different plantations (i.e. Tapah2, Shah Alam and Muar under Hap20), which had made the outbreak of infestation worse and difficult to control. According to a study by Silva-Brandao et al. (2013), two mtDNA data showed a higher number of shared haplotypes for estimating the origin of infestation from the southern region in Brazil. However, in this study the origin of infestation could not be estimated but had occurred simultaneously.

\section{CONCLUSION}

In this study, the phylogeography of the M. plana as determined by combining nuclear and mtDNA data in Peninsular Malaysia has shown the mixing of individuals among inter-populations, despite the distinct differences in geographic location. The mixing of individuals between populations had been supported by the haplotype analyses by presenting the high haplotype diversity $(\mathrm{Hd}=0.96089), 27$ haplotype numbers, haplotype network, and haplotype tree that indicated the possibility of gene flow between populations. These results suggest the occurrence of genetic exchange of the M. plana between plantations, which is possibly mediated by human activities such as translocation of plants to which the larvae of M. plana are attached, while the workers are visiting the various plantations, or it could be due to the ability of male M. plana to fly far across physical barriers and facilitated by winds. Here, we estimated that the infestation could 
have originated from three different plantations simultaneously, which then spread outwards as outbreaks of infestation which were difficult to control. However, further behavioural experiments need to be conducted before any solid conclusion can be derived regarding dispersal factors in M. plana. Consequently, the standard operating procedure and contingency measures should be continuously updated and implemented for the oil palm production sector to contain, control and therefore prevent the dispersal of this serious pest in the future.

\section{ACKNOWLEDGEMENT}

The authors would like to thank Mr. Mohd Firdaus Abu Naim from Felda Technoplant Office and MPOB for helps during the sampling process. The authors also wished to thank Dr. Maimon Abdullah for her kind editing and critical comments of the final draft copy of this publication. This study was financially supported by the research grant GUP-2018-037 and TP-K013317 from Universiti Kebangsaan Malaysia.

\section{REFERENCES}

Abdullah, F; Sabri, M S M; Sina, I; Fauzee, F and Isa, S M (2012). Response of the male bagworm moth (Metisa plana Walker, Lepidoptera: Psychidae) towards female bagworm pheromone lure in wind tunnel bioassays. Asia Life Sci., 21(2): 375-389.

Ahmad, M N; Kamarudin, N; Ahmad, S N; Arshad, O; Masri, M M M; Moslim, R and Kushairi, A (2017). Efficacy of pheromone trapping and aerial spraying of Bacillus thuringiensis (Bt) for controlling bagworm, Metisa plana Walker (Lepidoptera: Psychidae) in Yong Peng, Johor, Malaysia. J. Oil Palm Res., 29(1): 55-65.

Ali, S R R; Kamarudin, N; Wahid, M B; Ahmad, M N; Masri, M M M and Din, A K (2007). Sistem Pengurusan Perosak Bersepadu bagi Kawalan Ulat Bungkus di Ladang Sawit. MPOB, Bangi.

Aman-Zuki, A; Mohammed, M A;Md.-Zain, B M and Yaakop, $S$ (2019). Phylogenetic relationships of five oriental Apanteles species-groups (Hymenoptera: Braconidae: Microgastrinae) by concatenating four molecular markers. J. Asia-Pac. Entomol., 22(1): 341352.

Baird, A B; Braun, J K; Engstrom, M D; Holbert, A C; Huerta, M G; Lim, B K; Mares, M A; Patton, J C and Bickham, J (2017). Nuclear and mtDNA phylogenetic analyses clarify the evolutionary history of two species of native Hawaiian bats and the taxonomy of Lasiurini (Mammalia: Chiroptera). PLoS ONE, 12(10): e0186085. DOI: 10.1371/journal. pone. 0186085.

Basoalto, A; Ramírez, C C; Lavandero, B; Devotto, L; Curkovic, T; Franck, P and Fuentes-Contreras, E (2020). Population genetic structure of codling moth, Cydia pomonella (L.) (Lepidoptera: Tortricidae), in different localities and host plants in Chile. Insects, 11: 285.

Belshaw, R and Quicke, D L (1997). A molecular phylogeny of the Aphidiinae (Hymenoptera: Braconidae). Mol. Phylogenet. Evol., 7(3): 281-293. DOI: 10.1006/mpev.1996.0400.

Benson, D A; Cavanaugh, M; Clark, K; KarschMizrachi, I; Lipman, D J; Ostell, J and Sayers, E W (2013). GenBank. Nucleic Acids Res., 41: D36-D42. DOI: $10.1093 /$ nar/gks1195.

Campbell, B C; Steffen-Campbell, J D and Werren, J H (1994). Phylogeny of the Nasonia species complex (Hymenoptera: Pteromalidae) inferred from an internal transcribed spacer (ITS2) and 28S rDNA sequences. Insect Mol. Biol., 2(4): 225-237. DOI: 10.1111/j.1365-2583.1994.tb00142.x.

Elameen, A; Eiken, H G and Knudsen, G K (2016). Genetic diversity in apple fruit moth indicate different clusters in the two most important apple growing regions of Norway. Diversity, 8(2): 10.

Folmer, O; Black, M; Hoeh, W; Lutz, R and Vrijenhoek, R (1994). DNA primers for amplification of mitochondrial cytochrome c oxidase subunit I from diverse metazoan invertebrates. Mol. Mar. Biol. Biotechnol., 3(5): 294-299.

Godefroid, M; Rasplus, J Y and Rossi, J P (2016). Is phylogeography helpful for invasive species risk assessment? The case study of the bark beetle genus Dendroctonus. Ecography, 39(12): 1197-1209.

Halim, M; Aman-Zuki, A; Syed Ahmad, S Z; Mohammad Din, A M; Abdul Rahim, A; Mohd Masri, M M; Md Zain, B M and Yaakop, S (2018). Exploring the abundance and DNA barcode information of eight parasitoid wasps species (Hymenoptera), the natural enemies of the important pest of oil palm, bagworm, Metisa plana (Lepidoptera: Psychidae) toward the biocontrol approach and its application in Malaysia. J. Asia-Pac. Entomol., 21(4): 1359-1365.

Halim, M; Muhaimin, A M D; Syarifah Zulaikha, S A; Nor Atikah, A R; Masri, M M M and Yaakop, S (2017). Evaluation of infestation in parasitoids on Metisa plana Walker (Lepidoptera: Psychidae) in 
three oil palm plantations in Peninsular Malaysia. Serangga, 22(2): 135-149.

Halim, M; Syed Ahmad, S Z; Muhammad Din, A M and Yaakop, S (2019). The diversity and abundance of potential hymenopteran parasitoids assemblage associated with Metisa plana (Lepidoptera: Psychidae) in three infested oil palm plantations in Peninsular Malaysia. AIP Conf. Proc., 2111: 060024. DOI: $10.1063 / 1.5111286$.

Harrison, P M; Zheng, D; Zhang, Z; Carriero, N and Gerstein, M (2005). Transcribed processed pseudogenes in the human genome: An intermediate form of expressed retro sequence lacking proteincoding ability. Nucleic Acids Res., 33(8): 2374-2383.

Ho, C T; Yusof, I and Khoo, K C (2011). Infestation by the bagworms Metisa plana and Pteroma pendula for the period 1986-2000 in major oil palm estates managed by Golden Hope Plantations Berhad in Peninsular Malaysia. J. Oil Palm Res., 23: 1040-1050.

Jiang, J; Yu, J; Li, J; Li, P; Fan, Z; Niu, L; Deng, J; Yue, B and Li, J (2016). Mitochondrial genome and nuclear markers provide new insight into the evolutionary history of macaques. PLOS ONE, 11(5): e0154665. DOI: $10.1371 /$ journal.pone.0154665.

Kamarudin, N and Arshad, O (2016). Diversity and activity of insect natural enemies of the bagworm (Lepidoptera: Psychidae) within an oil palm plantation in Perak, Malaysia. J. Oil Palm Res., 28(3): 296-307.

Kamarudin, N; Ali, S R A; Masri, M M M; Ahmad, M N; Manan, C A H C and Kamarudin, N (2017). Controlling Metisa plana Walker (Lepidoptera: Psychidae) outbreak using Bacillus thuringiensis at an oil palm plantation in Slim River, Perak, Malaysia. J. Oil Palm Res., 29(1): 47-54.

Kang, J H; Yi, D-A; Kuprin, A V; Han, C and Bae, Y J (2021). Phylogeographic investigation of an endangered longhorn beetle, Callipogon relictus (Coleoptera: Cerambycidae), in Northeast Asia: Implications for future restoration in Korea. Insects, 12: 555 .

Kok, C C; Eng, O K; Razak, A R and Arshad, A M (2011). Microstructure and life cycle of Metisa plana (Lepidoptera: Psychidae). J. Sustain. Sci. Manag., 6(1): 51-59.

Krauthammer, M; Rzhetsky, A; Morozov, P and Friedman, C (2000). Using BLAST for identifying gene and protein names in journal articles. Gene, 259(1-2): 245-252. DOI: 10.1016/S03781119(00)00431-5.
Kumar, S; Stecher, G and Tamura, K (2016). MEGA7: Molecular evolutionary genetics analysis version 7.0 for bigger datasets. Mol. Biol. Evol., 33(7): 1870-1874.

Librado, P and Rozas, J (2009). DnaSP v5: A software for comprehensive analysis of DNA polymorphism data. Bioinformatics, 25(11): 1451-1452. DOI: 10.1093 / bioinformatics/btp187.

Liu, R Y; Yang, G S and Lei, C Z (2006). The genetic diversity of mtDNAD-loop and the origin of Chinese goats. Acta Genet. Sin., 33(5): 420-428.

Loong, C Y and Chong, T C (2012). Understanding pest biology and behavior for effective control of oil palm bagworms. Planter, 88(1039): 699-715.

Meemongkolkiat, T; Rattanawannee, $\mathrm{A}$ and Chanchao, C (2019). Genetic diversity of Apis spp. in Thailand inferred from $28 \mathrm{~S}$ rRNA nuclear and cytochrome b mitochondrial gene sequences. Psyche. p. 1-11.

Mohd-Yusof, N S; Senawi, J; Nor, S M and Md-Zain, B M (2020). Haplotype and network analysis of island flying fox (Pteropus hypomelanus) using D-loop region of mitochondrial DNA to confirm subspecies designation. Mamm. Res., 65(2): 375-385.

Muhammad Adhni Rusli (2018). Personal communication. MPOB, Bangi, Selangor, Malaysia.

Paradis, E (2018). Analysis of haplotype networks: The randomized minimum spanning tree method. Methods Ecol. Evol., 9(5): 1308-1317.

Patwardhan, A; Ray, S and Roy, A (2014). Molecular markers in phylogenetic studies - A review. J. Phylogenetics Evol. Biol., 2(2): 1-9.

Potineni, K and Saravanan, L (2013). Natural enemies of oil palm defoliators and their impact on pest population. Pest Manag. Hortic. Ecosyst., 19(2): 179-184.

Rahmat, N L; Zifruddin, A N; Zainal Abidin, C M R; Nor Muhammad, N and Hassan, M (2021). The developmental transcriptome of bagworm, Metisa plana (Lepidoptera: Psychidae) and insights into chitin biosynthesis genes. Genes, 12(1): 7.

Rhainds, M; Davis, D R and Price, P W (2009). Bionomics of bagworms (Lepidoptera: Psychidae). Annu. Rev. Entomol., 54: 209-226. DOI: 10.1146/ annurev.ento.54.110807.090448.

Rhainds, M; Gries, G; Ho, C T and Chew, P S (2002). Dispersal by bagworm larvae, Metisa plana: Effects of population density, larval sex, and host 
plant attributes. Ecol. Entomol., 27(2): 204-212. DOI: 10.1046/j.1365-2311.2002.00389.x.

Rhainds, M; Leather, S R and Sadof, C (2008). Polyphagy, flightlessness, and reproductive output of females: A case study with bagworms (Lepidoptera: Psychidae). Ecol. Entomol., 33(5): 663672. DOI: $10.1111 /$ j.1365-2311.2008.01027.x.

Ronquist, F; Teslenko, M; van der Mark, P; Ayres, D L; Darling, A; Höhna, S; Larget, B; Liu, L; Suchard, M A and Huelsenbeck, J P (2012). MrBayes 3.2: Efficient Bayesian phylogenetic inference and model choice across a large model space. Syst. Biol., 61(3): 539-542.

Salim, H; Md. Rawi, C S; Ahmad, A H and Abdo Al-Shami, S (2015). Efficacy of insecticide and bioinsecticide ground sprays to control Metisa plana Walker (Lepidoptera: Psychidae) in oil palm plantations, Malaysia. Trop. Life Sci. Res., 26(2): 73-83.

Silva-Brandao, K L; Almeida, L C; Moraes, S S and Cônsoli, F L (2013). Using population genetic methods to identify the origin of an invasive population and to diagnose cryptic subspecies of Telchin licus (Lepidoptera: Castniidae). Bull. Entomol. Res., 103(1): 89-97.

Simmons, R B and Weller, S J (2001). Utility and evolution of cytochrome b in insects. Mol. Phylogenet. Evol., 20: 196-210. DOI: 10.1006/ mpev.2001.0958.

Sudarsono, H; Purnomo, P and Hariri, A M (2011). Population assessment and appropriate spraying technique to control the bagworm (Metisa plana Walker) in North Sumatra and Lampung. Agrivita J. Agric. Sci., 33(2): 188-198. DOI: 10.17503/agrivita. v33i2.62.

Swofford, D L (2002). PAUP*: Phylogenetic Analysis Using Parsimony (*and Other Methods). Sinauer Associates, Massachusetts.

Tan, F; San-Lim, H and Abdullah, K (2011). The impact of the typhoon to Peninsular Malaysia on orographic effects. 2011 IEEE Symposium on Business, Engineering and Industrial Applications (ISBEIA), Langkawi, Malaysia. p. 286-291. DOI: 10.1109/ ISBEIA.2011.6088822.
Tan, K; Qu, Y; Wang, Z; Liu, Z and Engel, M S (2016). Haplotype diversity and genetic similarity among populations of the Eastern honey bee from HimalayaSouthwest China and Nepal (Hymenoptera: Apidae). Apidologie, 47(2): 197-205.

Templeton, A (2002). Out of Africa again and again. Nature, 416: 45-51. DOI: 10.1038/416045a.

Thaer, S; Kassim, F A; Hasbullah, N A and Al-Obaidi, J R (2021). Evaluation of bagworm, Metisa plana (Lepidoptera: Psychidae) infestation and beneficial parasitoid in an oil palm plantation, Perak, Malaysia. J. Sci. Math. Lett., 9(1): 19-35.

Thompson, J D; Higgins, D G and Gibson, T J (1994). CLUSTAL W: Improving the sensitivity of progressive multiple sequence alignment through sequence weighting, position-specific gap penalties and weight matrix choice. Nucleic Acids Res., 22(22): 4673-4680. DOI: 10.1093/nar/22.22.4673.

Vogler, A P and Welsh, A (1997). Phylogeny of North American Cicindela tiger beetles inferred from multiple mitochondrial DNA. Mol. Phylogenet. Evol., 8(2): 225-235.

Wood, B J and Kamarudin, N (2019). Bagworm (Lepidoptera: Psychidae) infestation in the centennial of the Malaysian oil palm industry - A review of causes and control. J. Oil Palm Res., 31(3): 364-380.

Wortley, A H; Rudall, P J; Harris, D J and Scotland, R W (2005). How much data are needed to resolve a difficult phylogeny? Case study in Lamiales. Syst. Biol., 54(5): 697-709.

Zhang, L; Cai, W; Luo, J; Zhang, S; Li, W; Wang, C; Lv, L and Cui, J (2018). Population genetic structure and expansion patterns of the cotton pest Adelphocoris fasciaticollis. J. Pest Sci., 91: 539-550.

Zhang, L-J; Cai, W-Z; Luo, J-Y; Zhang, S; Wang, C-Y; Lv, L-M; Zhu X-Z; Wang, Li and Cui, J-J (2017). Phylogeographic patterns of Lygus pratensis (Hemiptera: Miridae): Evidence for weak genetic structure and recent expansion in Northwest China. PLoS ONE, 12(4): e0174712. 